\title{
Application and Evaluation of Regional Control Technology of Limestone Water Hazard: A Case Study of the Gubei Coal Mine, North China
}

\author{
Jingzhong Zhu $\mathbb{D}^{1,2}$ Yu Liu $\mathbb{D}^{1},{ }^{1}$ Qimeng Liu $\mathbb{D}^{2},{ }^{2}$ Sen Yang, ${ }^{2}$ Jiajun Fan, ${ }^{2}$ Yu Cui, ${ }^{2}$ and Ling Li $^{2}$ \\ ${ }^{1}$ State Key Lab Mining Response \& Disaster Prevention \& Control, Anhui University of Science and Technology, \\ Huainan 232001, China \\ ${ }^{2}$ School of Earth and Environment, Anhui University of Science and Technology, Huainan 232001, China
}

Correspondence should be addressed to Yu Liu; yliu@aust.edu.cn

Received 10 December 2020; Revised 6 March 2021; Accepted 23 March 2021; Published 9 April 2021

Academic Editor: Nicoló Colombani

Copyright ( 92021 Jingzhong Zhu et al. This is an open access article distributed under the Creative Commons Attribution License, which permits unrestricted use, distribution, and reproduction in any medium, provided the original work is properly cited.

\begin{abstract}
The coal-forming period is mainly Permian and Carboniferous in the North China coalfield, which is one of the main coal accumulating areas in China. It is characterized by high coal rank, abundant reserves, and varieties. However, water outburst accidents originating from karst aquifers under the coal seam floor have become a terrible disaster in accompany with the deep coal exploited progressively. Water inrush events of the deep limestone have often occurred during excavation in mines. To decrease the risk of high confined water from the coal seam floor and ensure the mining under the safe water pressure of limestone aquifers, the comprehensive exploration and regional treatment are all implemented, such as drainage depressurization, curtain grouting, and grouting transformation of aquifers. Through the comprehensive treatment of the ground and underground, the water channel will be effectively filled with slurry to prevent limestone water bursting into the roadway, and the value of water-inrush coefficient is decreased below the critical value. In the study, utilizing COMSOL Multiphysics based on the finite element method to verify and determine the real layout of grouting parameters, the result shows the design plans satisfy the engineering requirements. 13321 working face located in South No.1 mining area has analyzed the effect of water hazard prevention and control. On the basis of the analysis of geophysical prospecting and validation boreholes, it is concluded that the fracture is filled with grouting slurry to block water-conducting channel effectively. In turn, the rational design parameters of grouting are confirmed as well. Finally, the water-inrush coefficient of Taiyuan formation limestone and Ordovician limestone water is calculated, respectively. The result shows that water-inrush coefficient is less than the critical value after treatment, the safety of excavating coal seam can be further assured.
\end{abstract}

\section{Introduction}

Although the energy consumption rate of coal resources is decreasing over time, it is still the main energy in domestic economic development. Coal consumption accounted for $57.7 \%$ of the total energy consumption in 2019. Besides, China ranks the first in coal production and consumption across the world. Mine water hazard has become one of the main factors restricting coal mine safety production. According to government statistics and the relevant literatures from 2009 to 2019 , a total of 238 accidents occurred in coal mines in China, resulting in around 1,000 deaths [1]. Once a water disaster occurs in a mine, it may cause mass deaths and injuries. For example, "3.1" Ordovician limestone water inrush event in Loutuoshan coal mine of Shenhua Group resulted in 32 deaths and 7 injuries [2] and " 3.28 " extraordinary water outburst accident in Wangjialing coal mine of Shanxi province caused 38 casualties and 115 injuries [3,4]. Although domestic has achieved remarkable performance in the decapacity of coal in recent years, water damage accidents caused by water hazards still continue to occur recently. For instance, the " 5.25 " Ordovician limestone water inrush 
accident occurred in Pan'er coal mine of Huainan coalfield in 2017 [5], the " $7 \cdot 6$ " accident in Zhuxianzhuang coal mine of Huaibei Coal Industry in 2018, and the "10.25" flood accident in Xigu Coal Industry of Xiang Mine Group in 2019.

It is precisely because of the great casualties and national economic losses caused by water hazards that contemporary scholars and researchers have studied water disaster-causing factors and mechanisms for decades. The complexity degree of geological structure studied by the intensity index, density of fault intersections, and endpoints has been put forward [6]. The thickness of aquicludes influencing on waterinrush resistance and water-filled channels is analyzed with the combination of rock lithology, such as the thickness and ration of sandstone and mudstone [7]. The theory of key strata is introduced to explain the result of water outbursts, that is, whether water inrush occurs or not mainly depends to a great extent on the key layers that consist of rock strata with high strength and low permeability $[8,9]$. Employing COMSOL Multiphysics numerical simulation software to compute the excavation-induced water outburst with the consideration of the faults and karst column [10, 11], water yield property and buried depth of limestone aquifer, aquitard hydraulic resistance, and structural characteristics are selected to investigate the possibility of Ordovician fissure confined water inrush [12]. The fractal dimension method on mine water inrush is utilized to predict the potential for water disaster quantitatively [13]. The damage depth of the coal seam floor destroyed during exploiting the working face at different elevations under the high confined aquifers is explained through FLAC ${ }^{3 \mathrm{D}}$ numerical simulation [14]. Meanwhile, hydrogeologists have put forth some methods of evaluating and predicting the risk of water inrush in recent years. The empirical formula of water-inrush coefficient is summarized from a large amount of statistical data analysis on water inrush events [15], then constantly modified and improved over time $[16,17]$. In addition, geophysical exploration methods, 3D high-density resistivity, direct current method, and 3D electric resistivity tomography also have been widely applied to forecast and assess the abundance and distribution of aquifers for years [18-20]. To ascertain the accurate location of anomaly zones, water-abundance characteristics, and flow paths of aquifers, one or several geophysical methods all have been adopted in previous studies [21].

Currently, research on water hazard control technology is gradually mature and complete as the technology and equipment remain to update and progress in practical engineering. According to the different hydrogeological conditions of coal mines, some appropriate preventive measures are taken to achieve the safety production. Gobs are usually threatened by separation layer water. By grouting into the overburden bedding separation, the displacement and deformation of overlying strata are obviously weakened; thus, the separation layer water could not burst into the rear of the mining area [22]. Considering North China coalfield threatened by limestone aquifers, some studies have focused on the control theory and technology of water inrush accidents resulting from high confined limestone aquifers $[23,24]$. Ordovician limestone aquifer has been successfully carried out the pregrout- ing based on the combination of geophysical exploration and drilling in the 8804 working face of Fengcheng mining area [25]. The ground pregrouting is implemented to reinforce the underground tunnel across the large fault areas in the Guqiao coal mine [26]. Directional drilling technology is applied to transform deep soft strata; evaluating methods of grouting effect is presented through the analysis of the engineering cases $[27,28]$. On the basis of systematic analysis on hydrogeological conditions, mine drainage is set about decreasing the risk of Carboniferous thin limestone aquifer threatening to the 16104 working face [29].

The main purpose of the paper is to introduce comprehensive treatment technology and evaluate the water damage of limestone. Taking the Gubei coal mine as an example, South No.1 mining area is surveyed by surface geophysical exploration before treatment firstly; the mine implemented multibranch directional hole and mine drainage to low pressure and level of limestone aquifers. Analyzing the validation of grouting hole layout, the grouting effect of the coal seam floor will be appraised by the data of underground geophysical exploration, observation holes, and verification drillings. The water-inrush coefficient is obtained to quantify the analysis of safety and efficient mining under the confined aquifer after treatment. The study summarizes a complete set of "exploration-treatment-evaluation" on the limestone disaster, which can provide the successful experience for other coal mines.

\section{Geology Synopsis}

2.1. Regional Geological Structure and Coal Measure Strata. Gubei mine is located in the middle east of Huainan coalfield situated in the southeastern margin of the North China Plate which is adjacent to Bengbu uplift in the north, Hefei basin in the south, Tanlu Fault in the east, and Shangqiu and Macheng Fault in the west, as shown in Figure 1. Huainan coalfield is a syncline form, and the main structural line is NWW trending. The tectonic movements that affect the development of coal measure strata mainly occurred in Indosinian Ages and Yanshanian Ages. The Yanshanian movement is not only characterized by folds and faults but also accompanied by magmatism. The Gubei coal mine is divided into four mining areas on the basis of the main faults developed in mine. North No.1 mining area and Central mining area have almost fully been excavated in recent years; South No.1 mining area is the third mining area in the coal mine in the next few years. The South No.1 mining area has six working faces (13121 working face 13621 working face) with the interval mining method, where 13121 coal face which is the first working face has been successfully exploited. The outcrop of 1 coal seam and weathered zone have been developed in the east of the mining area.

Gubei mine has lied in the connecting belt between the east wing of Chenqiao anticline and the west wing of Panji anticline. The overall structural form of the mine is a monoclinal structure with a north-south strike and an eastward dip. The strata slope gently, with the dips ranging from $5^{\circ}$ to $15^{\circ}$, and there are secondary wide and gentle folds and faults with uneven development. The sedimentary period of 


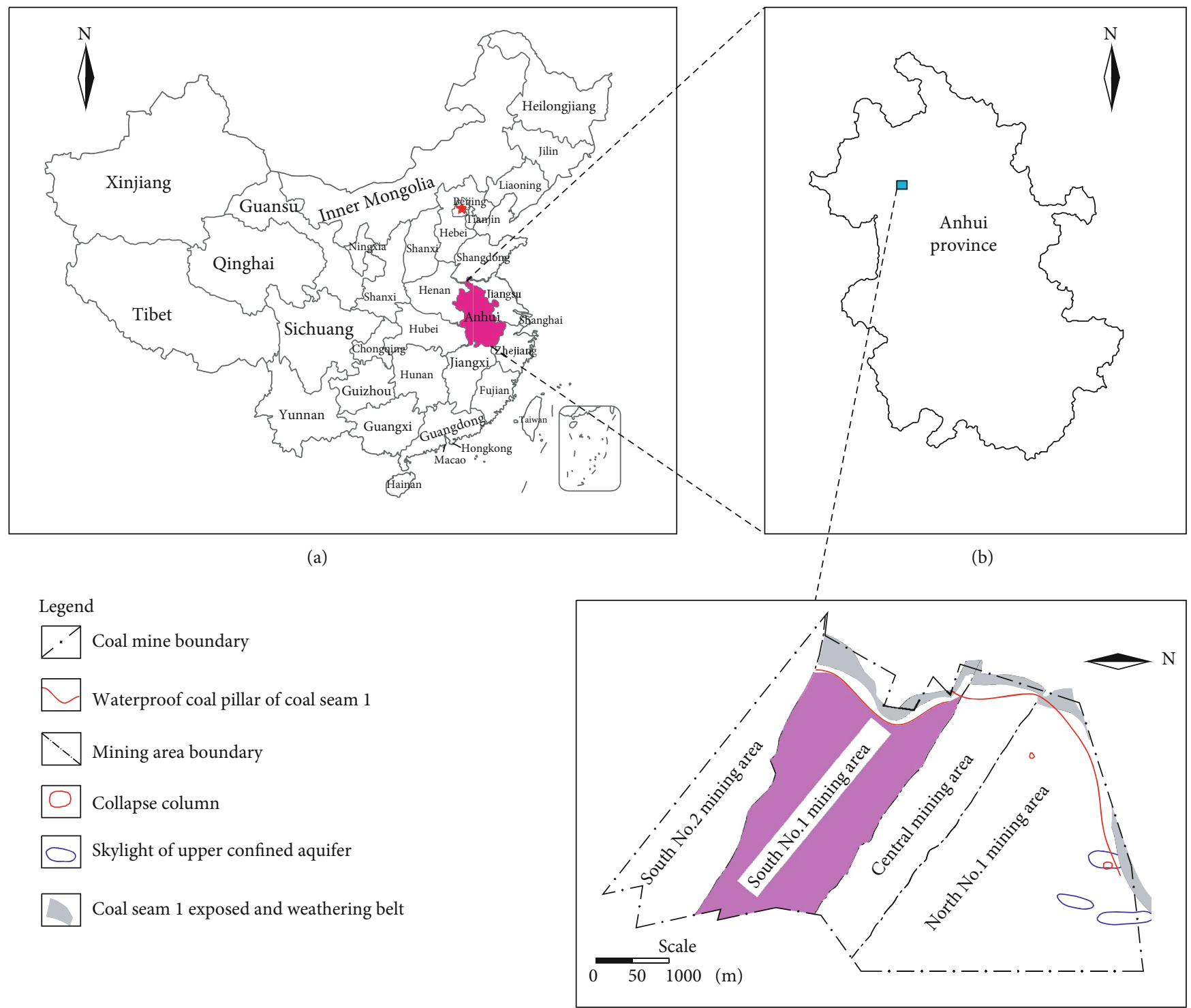

(c)

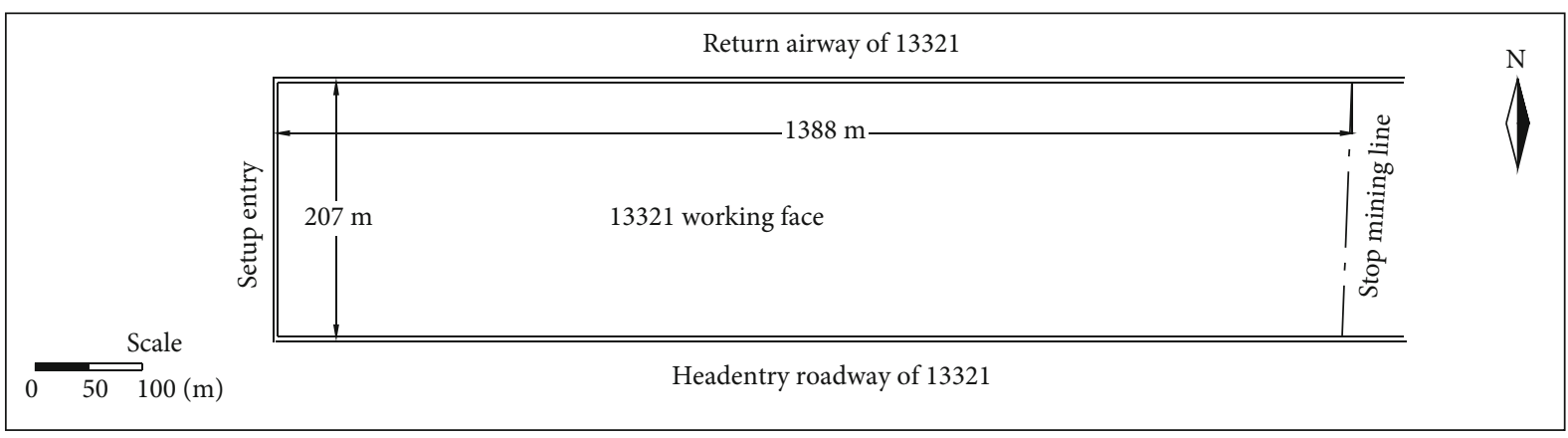

(d)

Figure 1: Location of the study area in China including (a), Huainan coalfield within Anhui province (b), schematic diagram of stope distribution (c), and 13321 working face located in South No.1 mining area (d).

coal measure strata in the coal mine is Carboniferous and Permian. The research area is a concealed coalfield. Drilling data reveal that the compound strata (from down to up) are consisted of the following: (1) Cambrian strata, which consist of dolomitic limestone, oolite limestone, limestone alternated with dolomitic limestone, and argillaceous limestone; (2) Ordovician strata, dolomitic limestone, breccia, locally developed with purplish-red and grayish-green argillaceous strips; 


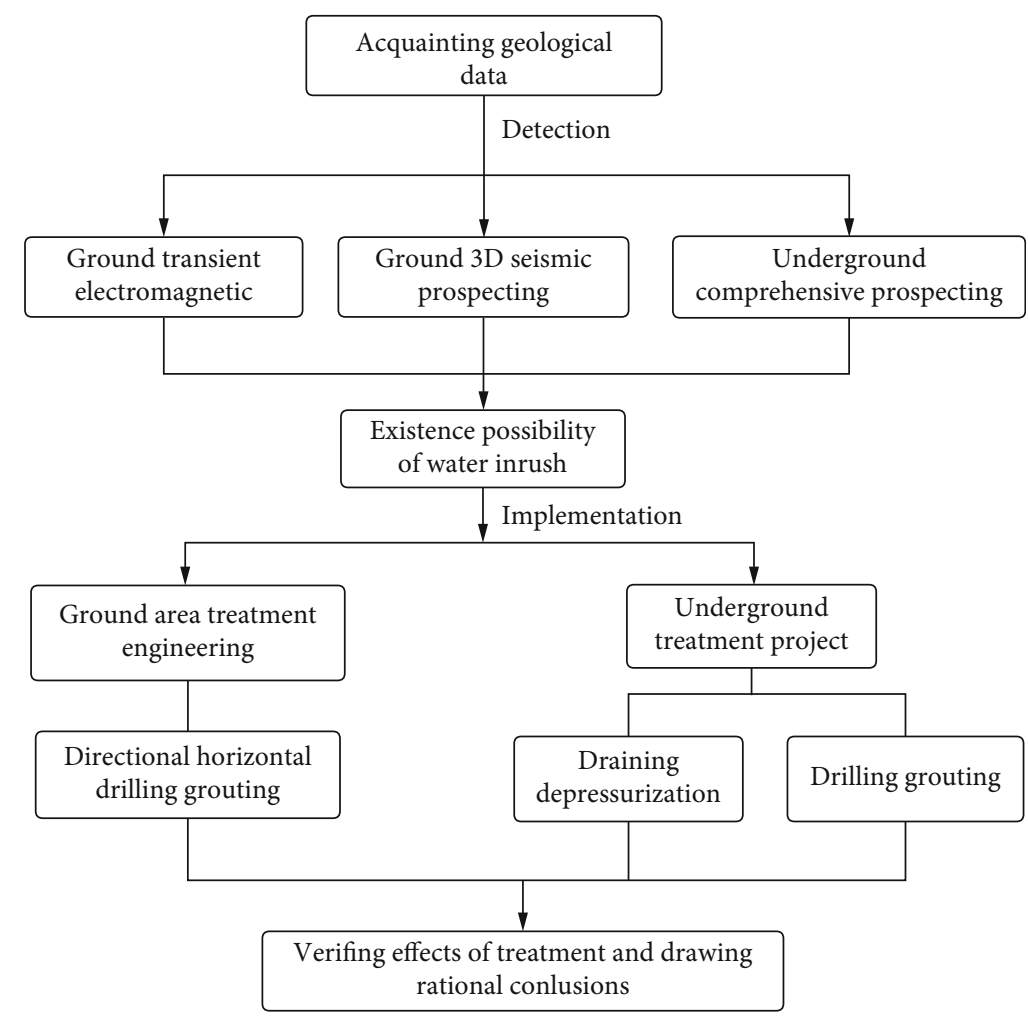

FIGURE 2: Flow chart of water inrush hazard prevention and control.

(3) Carboniferous strata, consisting of bioclastic limestone alternated with dark gray silty mudstone, interspersed with thin layers of carbonaceous mudstone and coal with no industrial use value; (4) Permian strata, with the main coalbearing strata, consisting of more than 30 coal-bearing layers. The minable coal seams comprise of 1 coal seam in the Permian Shanxi Group, 8 coal seam and 6 coal seam in the Permian Lower-Shihezi Group, and 11-2 coal seam and 13-1 coal seam in the Permian Upper-Shihezi Group; (5) Cenozoic strata, $371 \mathrm{~m} \sim 512.6 \mathrm{~m}$ in depth and directly covering the Permian coal measure strata, demonstrating thinner in the southeast and thicker in the northwest of the study area.

2.2. Hydrogeological Condition. According to early geological exploration and coal mining production data, aquifers threatening mine safety production include Cenozoic loose aquifers, sandstone fracture water in the Permian strata, karst fissure water in the Carboniferous limestone aquifers and Ordovician aquifers at present.

2.2.1. Loose Aquifers. The sedimentary thickness of the Cenozoic loose layer ranges between $371 \mathrm{~m}$ and $520.76 \mathrm{~m}$, with an average thickness of $456.51 \mathrm{~m}$, and the average elevation of the bedrock is $-419.77 \mathrm{~m}$. Based on the stratigraphic correlation and lithologic combination characteristics, it is divided into three aquifers, three water-resisting layers, and a red stratum at the bottom.

2.2.2. Sandstone Fissure Aquifers. Permian sandstone fracture aquifers are distributed between coal seam and mudstone; the lithology and thickness vary greatly. There are thick water-resistance layers consisting of mudstone and sandy mudstone between aquifers, which block the hydraulic connection between the sandstone fractured aquifers. The aquifers are mainly static reserves, with uneven water richness. The water inflow is generally not large; the supplement of condition and source is poor and limited. The waterresistance layer located between the 1 coal seam floor and the limestone aquifer roof is $10.07 \mathrm{~m}$ to $29.2 \mathrm{~m}$, with an average of $18.27 \mathrm{~m}$ in thickness.

2.2.3. Carboniferous Limestone Aquifers. The Carboniferous limestone aquifers are divided into three groups $\left(\mathrm{C}_{3} \mathrm{I}, \mathrm{C}_{3} \mathrm{II}\right.$, and $\mathrm{C}_{3}$ III groups) which consist of $10 \sim 12$ layers; $\mathrm{C}_{3} \mathrm{I}$ limestone aquifer is the direct source of water inrush from 1 coal seam floor. The maximum limestone water pressure of the coal seam floor is $3.5 \mathrm{MPa}$ measured at 1 coal belt conveyor roadway. Among them, six aquifers $\left(\mathrm{C}_{3}{ }^{1}, \mathrm{C}_{3}{ }^{3 \text { up }}, \mathrm{C}_{3}{ }^{3 \text { down }}\right.$, $\mathrm{C}_{3}{ }^{4}, \mathrm{C}_{3}{ }^{5}$, and $\mathrm{C}_{3}{ }^{11}$ ) are distributed stably, with thicker limestone than others. The unit water inflow of Taiyuan formation limestone ranges from $0.000597 \mathrm{~L} / \mathrm{m} \cdot \mathrm{s}$ to $0.299 \mathrm{~L} / \mathrm{m} \cdot \mathrm{s}$, the permeability coefficient varies greatly from $0.002 \mathrm{~m} / \mathrm{d}$ to $1.96 \mathrm{~m} / \mathrm{d}$, and the degree of water abundance is between weak and medium.

2.2.4. Ordovician Aquifers. About sixteen boreholes pass through Ordovician limestone strata in the mining area, with the thickness of $48.7 \mathrm{~m}$ to $92.5 \mathrm{~m}$. According to the drilling data, the lithology is dense without dissolution and no water leakage has rarely occurred during the borehole implementation. On the basis of the pumping test data, the water level elevation of Ordovician limestone is from $-5.85 \mathrm{~m}$ to 

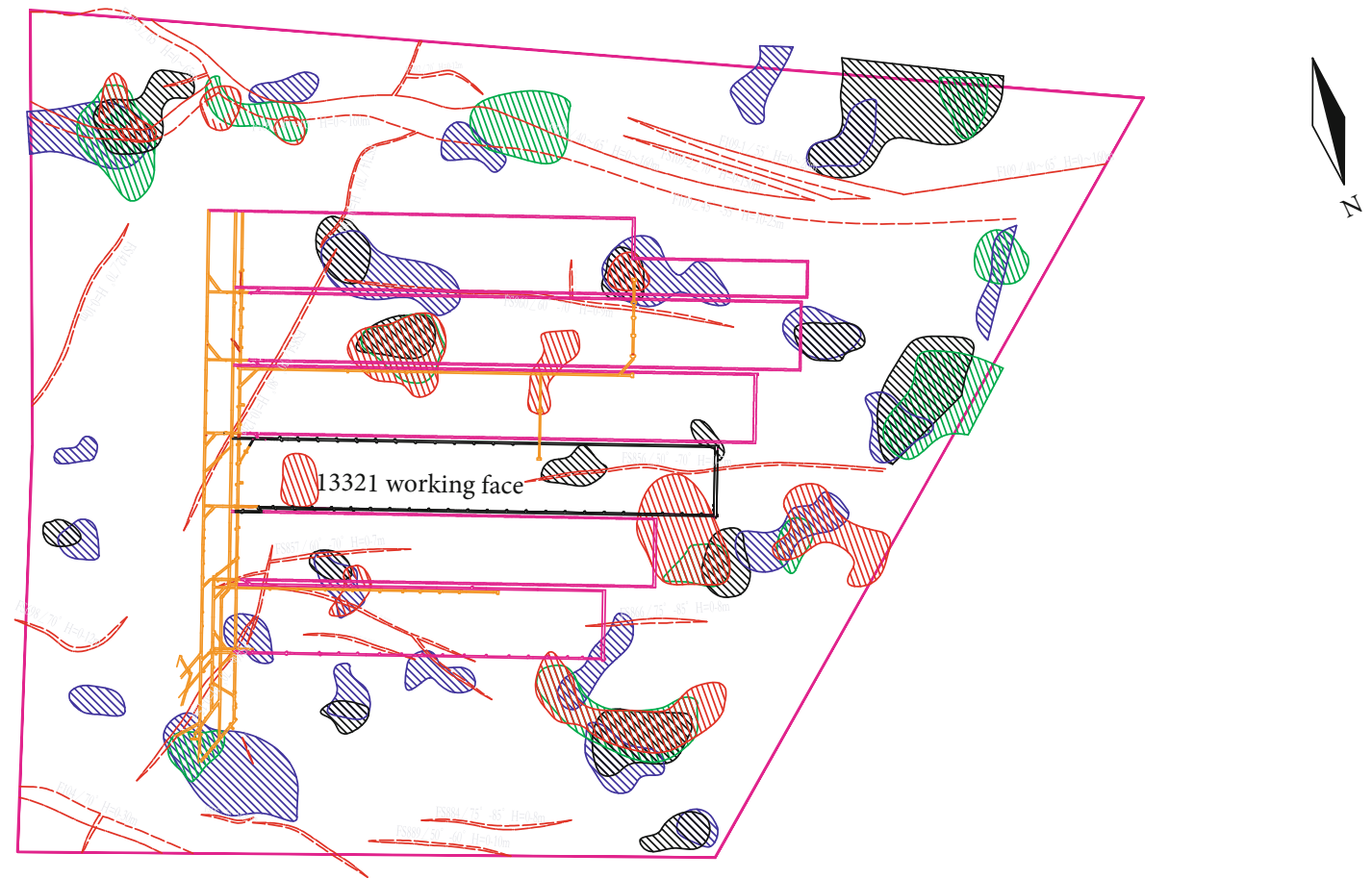

Legend
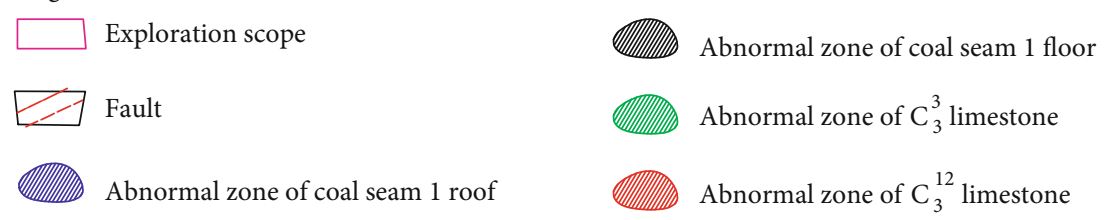

FIgURE 3: Water-abundance zone distribution of the South No.1 mining area, 13321 working face exists in two abnormal water-abundance zones of $\mathrm{C}_{3}{ }^{12}$ limestone and two sandstone fissure water-abundance zones.

$24.59 \mathrm{~m}$ and the unit water inflow is $0.000458 \mathrm{~L} / \mathrm{m} \cdot \mathrm{s}$ to $0.763 \mathrm{~L} / \mathrm{m} \cdot \mathrm{s}$, the degree of water abundance is weak to medium.

\section{Materials and Methods}

In the study, the 13321 working face of the South No.1 mining area in Gubei mine is analyzed to prevent and control limestone water inrush hazard under the 1 coal seam. From the detection of abundance zone using ground threedimensional seismic and underground comprehensive geophysical prospecting to the implementation of draining depressurization and ground grouting, the working face is made reasonable conclusions by evaluating the effect of water disaster control and treatment engineering finally. The procedure of research implementation is shown in Figure 2.

3.1. Geophysical Exploration. According to the priority investigation achievements of three-dimensional seismic and high power transient electron-magnetic exploration on the whole South No.1 mining area, although no collapse column is found, twenty-two low-resistance abnormal zones have existence in the 1 coal seam roof, fifteen low-resistance abnormal zones in the 1 coal seam floor, eleven low-resistance abnormal zones in the section of $\mathrm{C}_{3} \mathrm{I}$ group limestone, and eleven low resistance abnormal zones in $\mathrm{C}_{3}{ }^{12}$ limestone of Taiyuan formation. Among them, there are four abnormal zones with low resistance in the floor and margin of 13321 working face, including two water-abundance areas of 1 coal seam floor sandstone and two water-abundance zones of Taiyuan formation limestone under the 1 coal seam floor, as shown in Figure 3.

\subsection{Ground Region Treatment of Limestone Water Hazard.} On the basis of the detailed exploration on the limestone aquifers under the 1 coal seam floor, water-resistance layers should also have been considered into the study. The lithology of sedimentary strata related to aquiclude has been obtained from drillholes described by drawing a series of drillhole columnar sections to explain the occurrence status of water-resistance layers in the coal seam floor during early coalfield exploration. As shown in Figure 4, the average distance is $18.32 \mathrm{~m}$ between the 1 coal seam floor and the $\mathrm{C}_{3} \mathrm{I}$ group limestone roof. Meanwhile, the pressure of limestone aquifer is generally more than $2.0 \mathrm{MPa}$ in the whole study mining area; water-inrush coefficient is greater than the critical value of $0.10 \mathrm{MPa}$ required by the Detailed Rules for Coal Mine Water Prevention and Control. For this reason, ground region treatment is essential to be implemented for safety mining. 


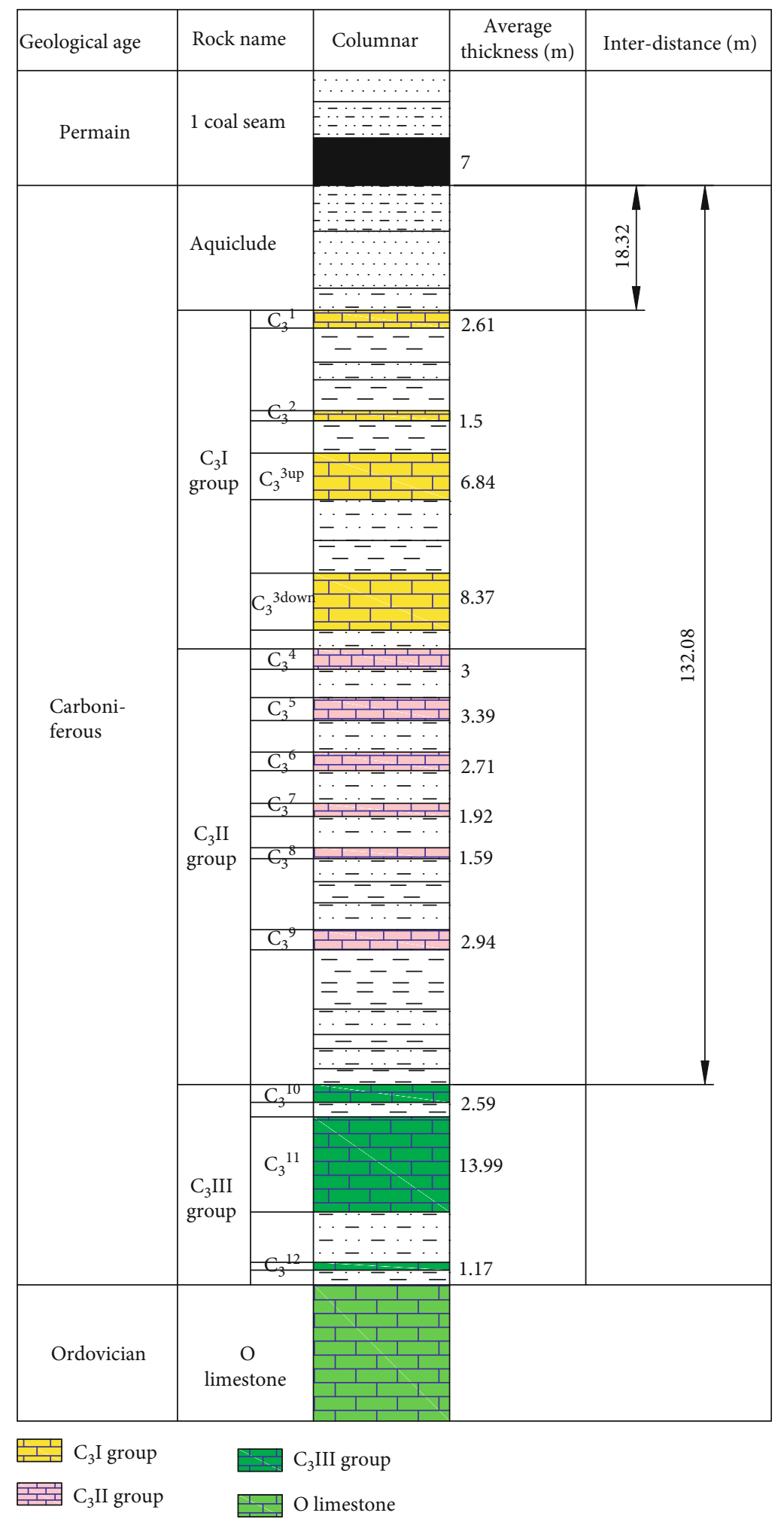

FIgUre 4: The comprehensive columnar of the mining area.

The scale of the South No.1 mining area is designed with near-horizontal multibranch drillings including five main grouting drillholes named as S1 S5; 13321 working face is covered by one main drillhole (S1) and its branch holes, and branch holes of other main drilling holes. The design principle of drilling is $60 \mathrm{~m} \times 60 \mathrm{~m}$ along the tendency and 


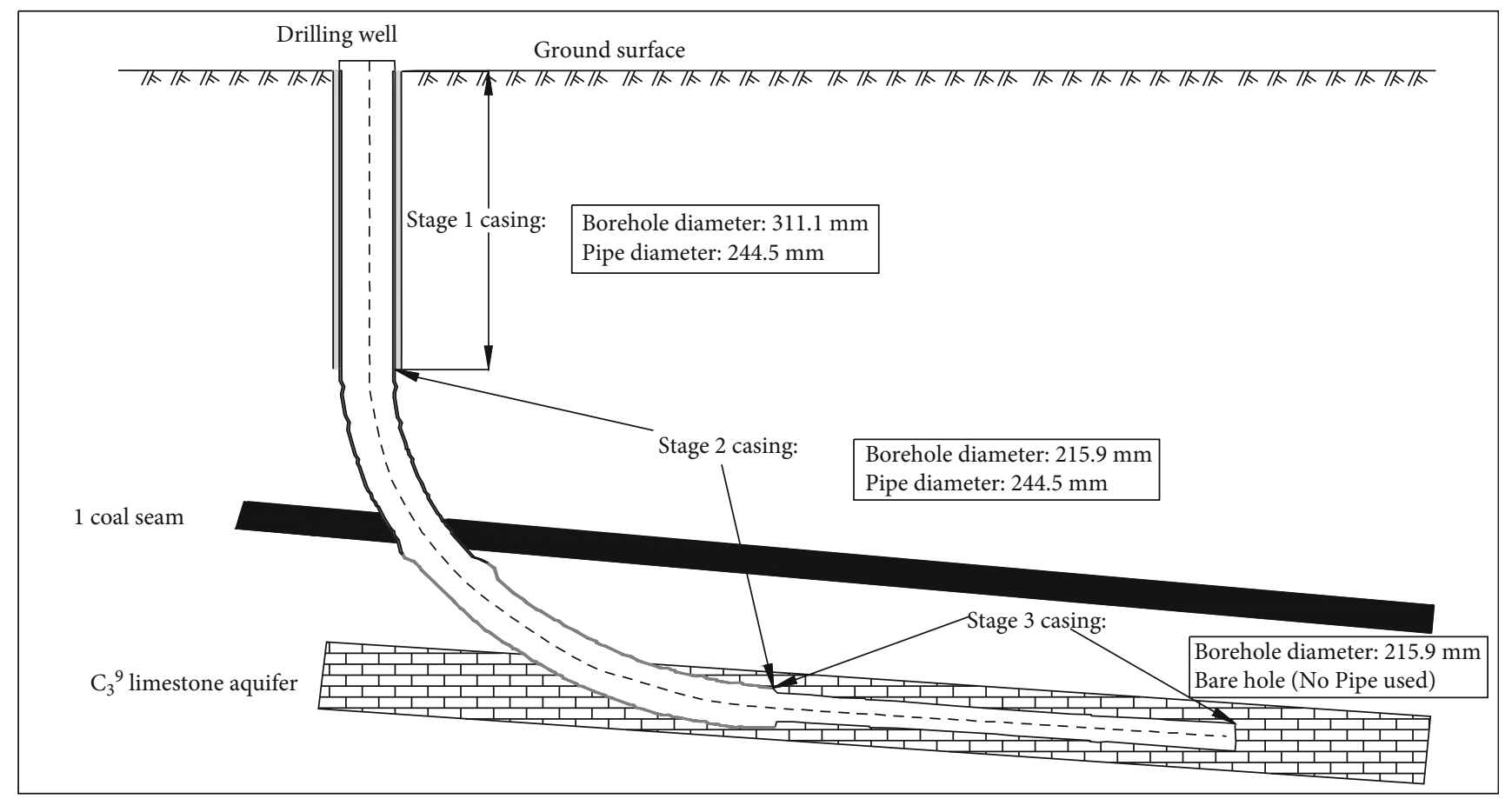

FIGURE 5: Schematic diagram of "three casings" drilling profile structure.

strike, with alternative drilling diameter. Figure 5 demonstrates the final position of the directional holes is located in the $\mathrm{C}_{3}{ }^{9}$ limestone aquifer.

To verify whether the rational layout of borehole spacing or not, the numerical simulation method is employed to analyze the influence radius of grouting diffusion at different situations, such as grouting pressure, water-cement ratio (R), and dynamic viscosity. COMSOL Multiphysics numerical simulation software based on finite element theory is utilized to complete the study of grouting diffusion [30]. Because the water-cement ratio is greater than 1.0 in the study, the grouting fluid belongs to Newtonian fluid with incompressible property. Constitutive equations of Newton fluid are described as follows:

$$
\begin{gathered}
\tau_{x y}=\tau_{y x}=\mu\left(\frac{\partial u}{\partial y}+\frac{\partial v}{\partial x}\right), \\
\tau_{y z}=\tau_{z y}=\mu\left(\frac{\partial v}{\partial z}+\frac{\partial w}{\partial y}\right), \\
\tau_{z x}=\tau_{x z}=\mu\left(\frac{\partial w}{\partial x}+\frac{\partial u}{\partial z}\right), \\
\sigma_{x x}=-p+2 \mu \frac{\partial u}{\partial x}-\frac{2}{3} \mu\left(\frac{\partial u}{\partial x}+\frac{\partial v}{\partial y}+\frac{\partial w}{\partial z}\right), \\
\sigma_{y y}=-p+2 \mu \frac{\partial v}{\partial x}-\frac{2}{3} \mu\left(\frac{\partial u}{\partial x}+\frac{\partial v}{\partial y}+\frac{\partial w}{\partial z}\right), \\
\sigma_{z z}=-p+2 \mu \frac{\partial w}{\partial x}-\frac{2}{3} \mu\left(\frac{\partial u}{\partial x}+\frac{\partial v}{\partial y}+\frac{\partial w}{\partial z}\right),
\end{gathered}
$$

where $\tau$ is the shear stress; $\mu$ is the hydrodynamic viscosity coefficient; $\partial u / \partial x, \partial v / \partial y, \partial w / \partial z$ are the shear deformation rate in three-dimensional direction; $p$ is the static pressure.

Two-phase Darcy's law is applied to compute the grouting diffusion in two dimensions. The hypothesis equations of two-phase Darcy flow are expressed as follows:

$$
\begin{aligned}
& \frac{\partial \varepsilon_{p} \rho}{\partial \mathrm{t}}+\nabla \cdot(\rho \mathbf{u})=0, \quad \mathbf{u}=-\frac{k}{\mu} \nabla p, \\
& \rho=s_{1} \rho_{1}+s_{2} \rho_{2}, \frac{1}{\mu}=s_{1} \frac{\kappa_{r 1}}{\mu_{1}}+s_{2} \frac{\kappa_{r 2}}{\mu_{2}}, s_{1}+s_{2}=1, \\
& \partial \varepsilon_{p} c 1 \\
& \frac{\partial \mathrm{t}}{}+\nabla \cdot(c 1 \mathbf{u})=\nabla \cdot\left(D_{C} \nabla c 1\right), \quad c 1=s_{1} \rho_{1} .
\end{aligned}
$$

where $\varepsilon_{p}$ is the rock porosity; $\rho$ is the average density of mixture fluids; $c 1$ is the fluid content; $\rho_{i}$ is the specific fluid density; $u$ is the velocity; $s_{i}$ is the proportion of each fluid; $\kappa_{r i}$ is the relative permeability of specific fluid; $\mu_{i}$ is dynamic viscosity of specific fluid; $\mu$ is the average dynamic viscosity of mixture fluids.

The single borehole is analyzed in the geometry model with the size of $100 \mathrm{~m} \times 100 \mathrm{~m}$, located in (50,50). After the parameters and boundary conditions are set, the model is performed to create the mesh element whose size is predefined in the extra fine.

Through the simulation of slurry diffusion, the result shows that the scale of slurry diffusion is positively correlated with the grouting pressure and inversely proportional to the dynamic viscosity and water-cement ration at the same time [31]. The scale of slurry diffusion presents three circle layers, 


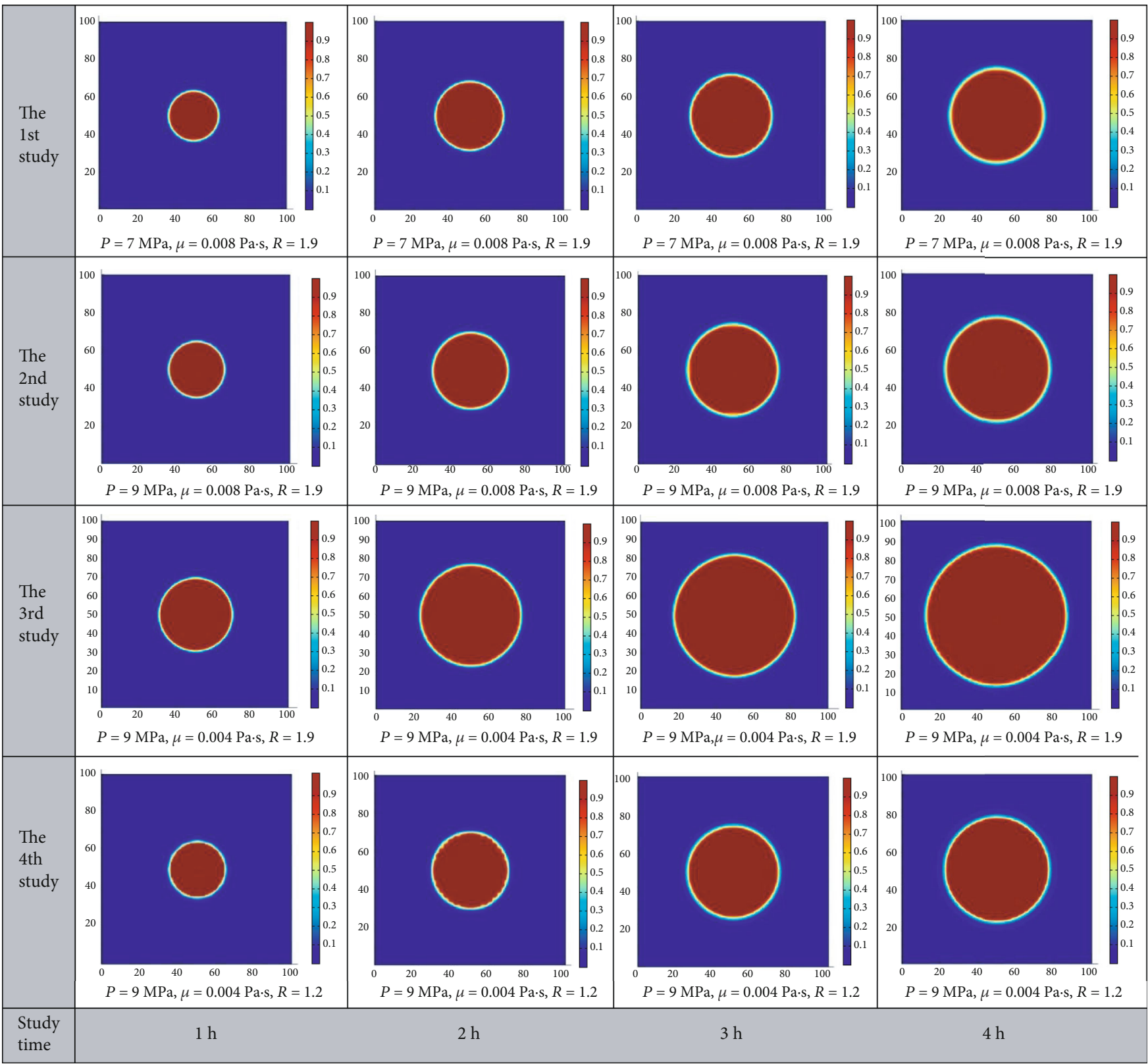

FIGURE 6: The distribution plot of slurry diffusion at different situation with time.

the center circle stands for compressive filling zone, the second circle layer is semistress filling zone, and the outmost layer is the free outflow zone, as shown in Figure 6. In the 1st study, when the grouting pressure is $7 \mathrm{MPa}$, the dynamic viscosity is $0.008 \mathrm{~Pa} \cdot \mathrm{s}$, and the water-cement ratio is 1.9 , the radius of slurry diffusion is around $27.5 \mathrm{~m}$ after 4 hours. However, the grouting pressure increases to $9 \mathrm{MPa}$ and other parameters remain unchanged; the radius of slurry diffusion increases by $2.5 \mathrm{~m}$ after 4 hours (that is to say, the radius of slurry diffusion is $30 \mathrm{~m}$ ) in the $2 \mathrm{nd}$ study. On the foundation of the 2nd study, the conclusion that the radius of slurry diffusion negatively correlated with dynamic viscosity is confirmed by adjusting the parameter value of dynamic viscosity. The scale of slurry diffusion becomes apparently enlarged than before, increasing to $40 \mathrm{~m}$ or so in the $3 \mathrm{rd}$ study. Lastly, the water-cement ratio is changed into 1.2 , and the other parameters are the same with ones of the 3rd study. It is found that the radius of slurry diffusion drops to $30 \mathrm{~m}$ in comparison with the $3 \mathrm{rd}$ study, and the result is almost the same as the result of the 2 nd study yet.

In practical engineering, the performance parameters of slurry are selected as follows: (1) the minimum grouting pressure in all boreholes is given to $9.2 \mathrm{MPa}$, which is more than 1.5 times of Ordovician limestone water pressure; (2) dynamic viscosity and water-cement ratio are set to $0.006 \mathrm{~Pa} \cdot \mathrm{s}$ and 2.0 , respectively. In terms of grouting simulation before-mentioned, the current ground grouting treatment projects can fully meet the requirement of drilling spacing, which play a vital role in reinforcement of the waterproof layer and block the invasion of deep high confined limestone water. 

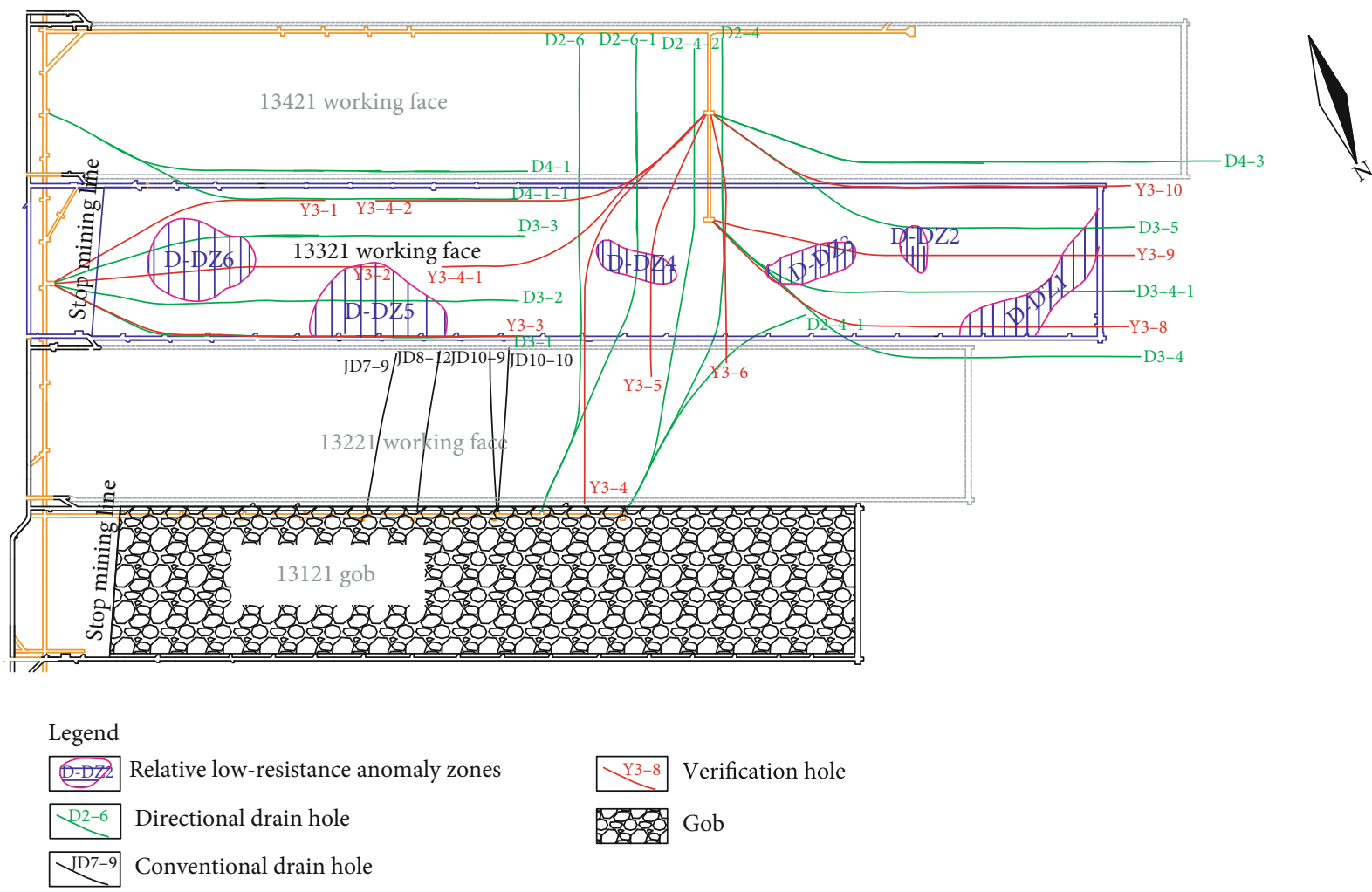

FIGURE 7: Comprehensive geophysical abnormal interpretation of 13321 working face floor and holes for regional control verification layout.

3.3. Draining Depressurization. Carrying out regional treatment on the ground and underground draining depressurization is performed to assure the safety of working face mining at 13121 bed plate tunnel, 13141 bed plate tunnel, and 1 coal floor drainage roadway. The eighteen boreholes, including fourteen directional horizontal holes and four conventional holes, fully cover the whole 13321 working face. By using the artificial drainage measure to lower the limestone water level and pressure [32], the water-inrush coefficient is decreased below the critical value; the safety coefficient has been further improved.

3.4. Validation of Treatment Engineering Effect. After comprehensive treatment of limestone water hazard of 1 coal seam floor, the effect of treatment engineering has been confirmed to employ multimethods, such as drilling and geophysical exploration. During the excavation of the belt conveyor bed plate tunnel and return airway bed plate tunnel of the 13321working face, the comprehensive geophysical prospecting (transient electromagnetic and current electric method) combined with regular drillings is used to predict the occurrence of water body in roadway front. It is proven that no low-resistance abnormal area and the phenomenon of borehole water inflow is rarely found during excavation.

While the construction of 13321 working face is thoroughly completed, a three-dimension electrical method and audio-frequency electrical perspective technology are used to further ascertain the water-abundance situation of the limestone aquifers of 1 coal seam floor. Through the comprehensive analysis of geophysical prospecting, six abnormal water-abundance zones have existence within $60 \mathrm{~m}$ of the
13321 working face floor, which are designated D-DZ1, DDZ2, D-DZ3, D-DZ4, D-DZ5, and D-DZ6; the detailed location is shown in Figure 7.

Based on the verification concept of "geophysical exploration first, drilling supplement," the mine designs eleven long verification boreholes in the drainage roadway of 1 coal seam floor and the drainage crossheading of 13421 belt conveyor bed plate tunnel, which verify the water-abundance of six low-resistance abnormal zones in the working face and confirm regional treatment effect of the 13321 working face floor in the early stage as well. At least two boreholes are drilled through the abnormal zones during the implementation project, which reduces the uncertainty of interpretation. It is ascertained that there has no water existence in D-DZ4; other low-resistance abnormal zones are verified to have a small amount of water inflow from drilling holes, with the water volume of $0.1 \mathrm{~m}^{3} / \mathrm{h} \sim 1.0 \mathrm{~m}^{3} / \mathrm{h}$ and the water temperature of $30^{\circ} \mathrm{C} \sim 35^{\circ} \mathrm{C}$ which is lower than the average temperature of Ordovician limestone by $39^{\circ} \mathrm{C}$. Therefore, the degree of water abundance in the low-resistance abnormal zones is weak, the water recharge channel has been effectively sealed by grouting, and Taiyuan formation limestone aquifers have no supplement of deep Ordovician limestone water.

In terms of water inflow in the borehole, water pressure, and water temperature, the control and treatment effect of limestone water hazard obviously fulfills the prior expectation goal. As shown in Table 1, five of the eleven verification drillings have no water (Y3-1, Y3-4, two branches of Y3-4, and Y3-5); other drillings only drip occasionally in small water volume with lower water pressure in comparison with the water pressure measured before regional treatment. 
TABLE 1: Regional exploration and treatment effect verification of outlet drilling.

\begin{tabular}{|c|c|c|c|c|c|c|}
\hline Bore no. & Hole depth (m) & $\begin{array}{l}\text { Water exit } \\
\text { formation }\end{array}$ & $\begin{array}{l}\text { Water inflow } \\
\left(\mathrm{m}^{3} / \mathrm{h}\right)\end{array}$ & $\begin{array}{c}\text { Water temperature } \\
\left({ }^{\circ} \mathrm{C}\right)\end{array}$ & $\begin{array}{c}\text { Water pressure } \\
(\mathrm{MPa})\end{array}$ & $\begin{array}{l}\text { Water quality } \\
\text { type }\end{array}$ \\
\hline$\overline{\text { Y3-2 }}$ & 471 & $\mathrm{C}_{3}{ }^{3 \text { down }}$ limestone & 0.30 & 30 & 0 & $\mathrm{Cl} \cdot \mathrm{HCO}_{3}-\mathrm{Na}+\mathrm{K}$ \\
\hline Y3-6 & 351 & $\mathrm{C}_{3}^{3 \text { down }}$ limestone & 0.42 & 32 & 0.10 & $\mathrm{Cl} \cdot \mathrm{HCO}_{3}-\mathrm{Na}+\mathrm{K}$ \\
\hline Y3-8 & 636 & $\mathrm{C}_{3}{ }^{5}$ limestone & 0.10 & 35 & 0 & $\mathrm{Cl} \cdot \mathrm{HCO}_{3}-\mathrm{Na}+\mathrm{K}$ \\
\hline Y3-9 & 597 & $\mathrm{C}_{3}{ }^{5}$ limestone & 1.00 & 34 & 0 & $\mathrm{Cl} \cdot \mathrm{HCO}_{3}-\mathrm{Na}+\mathrm{K}$ \\
\hline Y3-10 & 615 & $\mathrm{C}_{3}{ }^{5}$ limestone & 0.30 & 34 & 0.70 & $\mathrm{Cl} \cdot \mathrm{HCO}_{3}-\mathrm{Na}+\mathrm{K}$ \\
\hline
\end{tabular}

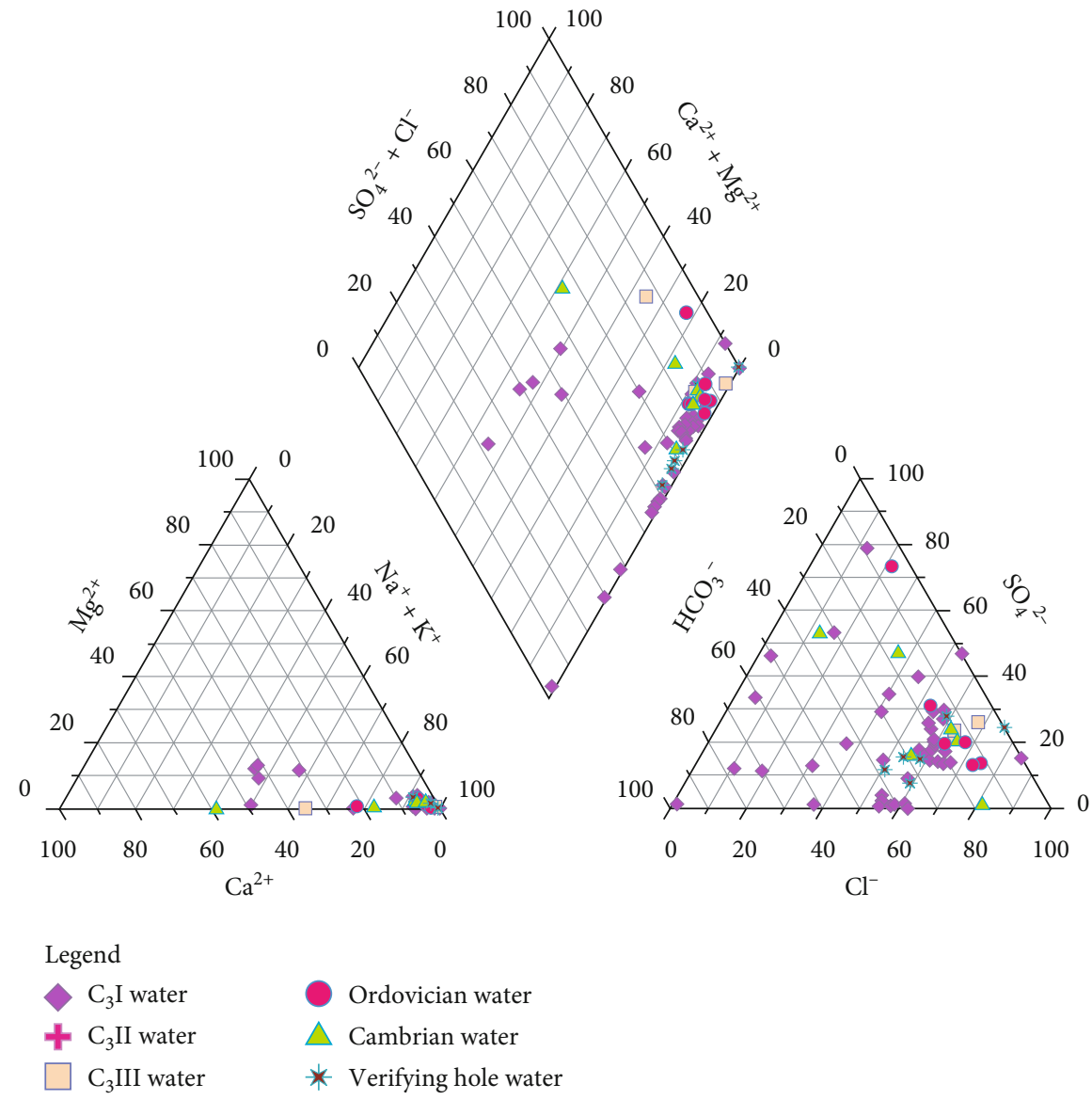

Figure 8: Comparative analysis of water chemistry characteristics. Taiyuan formation limestone water $\left(\mathrm{C}_{3} \mathrm{I}, \mathrm{C}_{3} \mathrm{II}\right.$, and $\mathrm{C}_{3} \mathrm{III}$ groups), Ordovician limestone water, and Cambrian limestone water act as the background value to analyze to discriminate the verification hole outflow water sources.

Furthermore, analysis of aquifer chemistry can discriminate the source of validation hole water compared with the water chemistry characteristics in Carboniferous and Ordovician limestone aquifers [33-35]. The result is that the quality type of the water samples (Y3-2, Y3-6, Y3-8, Y3-9, and Y3-10) is apparently different from that of Ordovician limestone, but similar to that of Taiyuan formation limestone aquifers, as shown in Figure 8. The chemistry component of Taiyuan formation limestone water is mainly characterized by $\mathrm{Cl} \cdot \mathrm{HCO}_{3}$ $\mathrm{Na}+\mathrm{K}$, Ordovician limestone water is characterized as $\mathrm{SO}_{4} \cdot \mathrm{HCO}_{3}-\mathrm{Na}+\mathrm{K}$, and the trait of Cambrian limestone water chemistry is $\mathrm{Cl}-\mathrm{Na}+\mathrm{K}$ and $\mathrm{SO}_{4}-\mathrm{Na}+\mathrm{K}$. The three types of water sources have in common with positive irons, but the anions are distinguishable from each other. Thus, the verification hole water source could be judged by anion components. In summary, all evidence can certify the validation of limestone water damage prevention and control properly.

\section{Results and Discussions}

After ground regional treatment and the validation of the grouting effect, a reasonable and qualitative evaluation can be made on the prevention and treatment effect of limestone water. Water-conducting fissure is fully filled with slurry, consolidating the waterproof floor of 1 coal seam and increasing the effective thickness of the waterproof layer. 

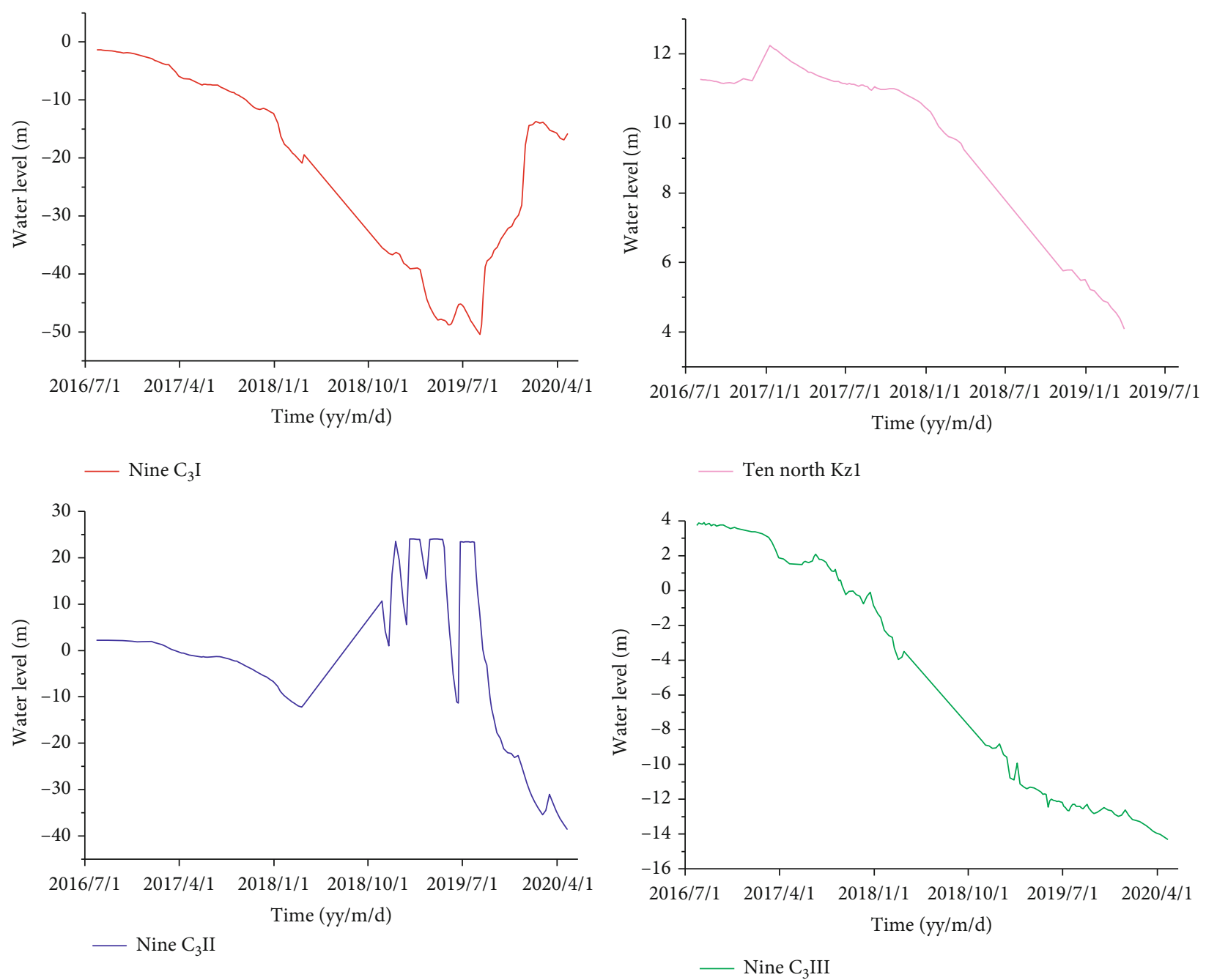

FIGURE 9: Hydrogeological observation well dynamic curves of Carboniferous limestone aquifers $\left(\mathrm{C}_{3} \mathrm{I}, \mathrm{C}_{3} \mathrm{II}\right.$, and $\mathrm{C}_{3} \mathrm{III}$ groups) in South No.1 mining area after water damage prevention and treatment.

Meanwhile, the water pressure and level of limestone aquifers have been significantly decreased by mine drainage and grouting on the analysis data of the hydrogeological observation wells located in the South No.1 mining area.

In the South No.1 mining area and nearby, there are seven observation wells for monitoring water level change of limestone aquifers, which contain four Carboniferous observation wells (that is, nine $\mathrm{C}_{3} \mathrm{I}$, ten north $\mathrm{Kz} 1$, nine $\mathrm{C}_{3} \mathrm{II}$, and nine $\mathrm{C}_{3} \mathrm{III}$ ), two Ordovician observation wells (nine $\mathrm{O}_{1+2}$-I and ten-ten south $\mathrm{O}_{1+2}$ ), and one Cambrian observation well (XLZJ1).

As shown in Figure 9, without the implementation of regional control and treatment, the water level of Carboniferous aquifers is usually maintained within the range of $-1.6 \mathrm{~m}$ to $12 \mathrm{~m}$. From the second half of 2016, the mine set about practicing regular inspection and drainage hole during the excavation of 1 coal face bed plate tunnel combines with directional long drain holes. In early 2017, the underground water level gradually declined to varying extents. Although the fluctuant phenomenon of the $\mathrm{C}_{3} \mathrm{I}$ and $\mathrm{C}_{3} \mathrm{II}$ group water level occurred in nine $\mathrm{C}_{3} \mathrm{I}$ and nine $\mathrm{C}_{3} \mathrm{II}$ which are situated at the boundary of the mining area, the overall tendency of the limestone aquifer level was declining. It is analyzed that the fluctuation of water level arises from grouting. In other words, slurry diffusion forces in situ water body to flow into the nongrouting area, causing the observation water level to rise; enforcement of mine drain and multiple grouting in different periods results in water level with ups and downs finally [36]. As the continuous drainage to be performed, the water level and quantity of limestone water in the working face floor are decreasing.

Because of the short distance between Carboniferous strata and limestone aquifers in the Ordovician and Cambrian. Fracture-conducting has the existence between strata. Thus, while water in the Taiyuan formation has been draining, Ordovician and Cambrian limestone aquifers are indirectly dewatered as well. After water hazard prevention and treatment, the water level drops by more than $10 \mathrm{~m}$, as shown in Figure 10.

According to the safety evaluation methods of limestone water disaster in North China coalfield by previous scholars and experts, the water-inrush coefficient method is applied 

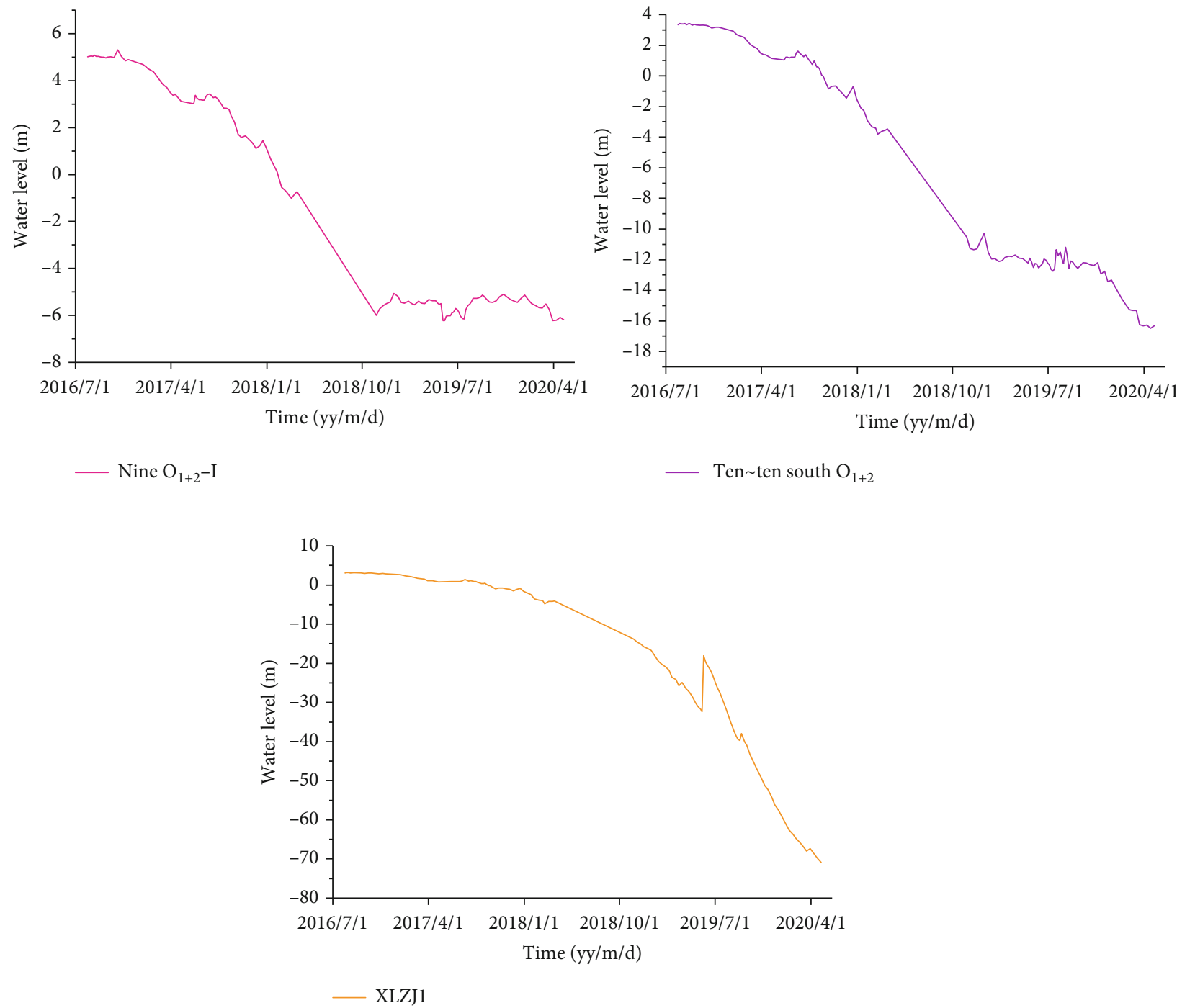

Figure 10: Hydrological observation well dynamic curve of Ordovician and Cambrian limestone aquifers in the South No.1 mining area before and after water damage prevention and treatment.

to assess the feasibility and safety after treatment in the study. The evaluation method is employed to predict the safety of coal mines in North China during production, which is first incorporated into "the Regulations for Coal Mine Water Prevention and Control, China" (Ministry of Coal Industry 2009) and is partially modified in 2018 [37]. Based on the latest Coal Mine Water Prevention and Control Rules, the water-inrush coefficient is expressed as follow:

$$
T_{s}=\frac{P}{M}
$$

where $T_{s}$ is the water-inrush coefficient with bearing pressure of the unit aquitard thickness $(\mathrm{MPa} / \mathrm{m}) ; P$ is the aquifer water pressure endured by the coal seam floor (MPa); $M$ is the aquitard thickness which is defined as the distance between coal seam floor and aquifer roof; the data of $M$ is derived from geological drillholes.

After implementing limestone water hazard regional treatment and control projects, the direct limestone aquifer (namely, $\mathrm{C}_{3} \mathrm{I}$ group aquifer) has rarely threatened to 1 coal seam. By analyzing the data of limestone drilling exposed in 13321 working face, the lithology between 1 coal seam floor and $\mathrm{C}_{3} \mathrm{I}$ group limestone roof is mainly sandy mudstone, siltstone, fine sandstone, and mudstone, which can be regarded as the water-resistance layer with a thickness of $16.5 \mathrm{~m}$ to $21 \mathrm{~m}$ and the average of $17.9 \mathrm{~m}$; the value of $M$ is given to $16.5 \mathrm{~m}$ for the sake of safety in the study. Considering the calculating results and pressure-measurement drilling data, pressure-bearing of 1 coal seam floor, the rational value is determined by $0.55 \mathrm{MPa}$. According to Equation (3) listed above, water-inrush coefficient is calculated as $0.033 \mathrm{MPa}$.

Considering the water inrush accident of Ordovician limestone aquifers in some coal mines recently, it should be treated equally as the Carboniferous limestone aquifer, although it is defined as the indirect recharge water source. Combined with the actual geological condition of 13321 working face and water damage control projects, the strata from $\mathrm{C}_{3}{ }^{9}$ limestone floor to the 1 coal seam floor are treated as the aquiclude layer of the Ordovician limestone aquifer, 

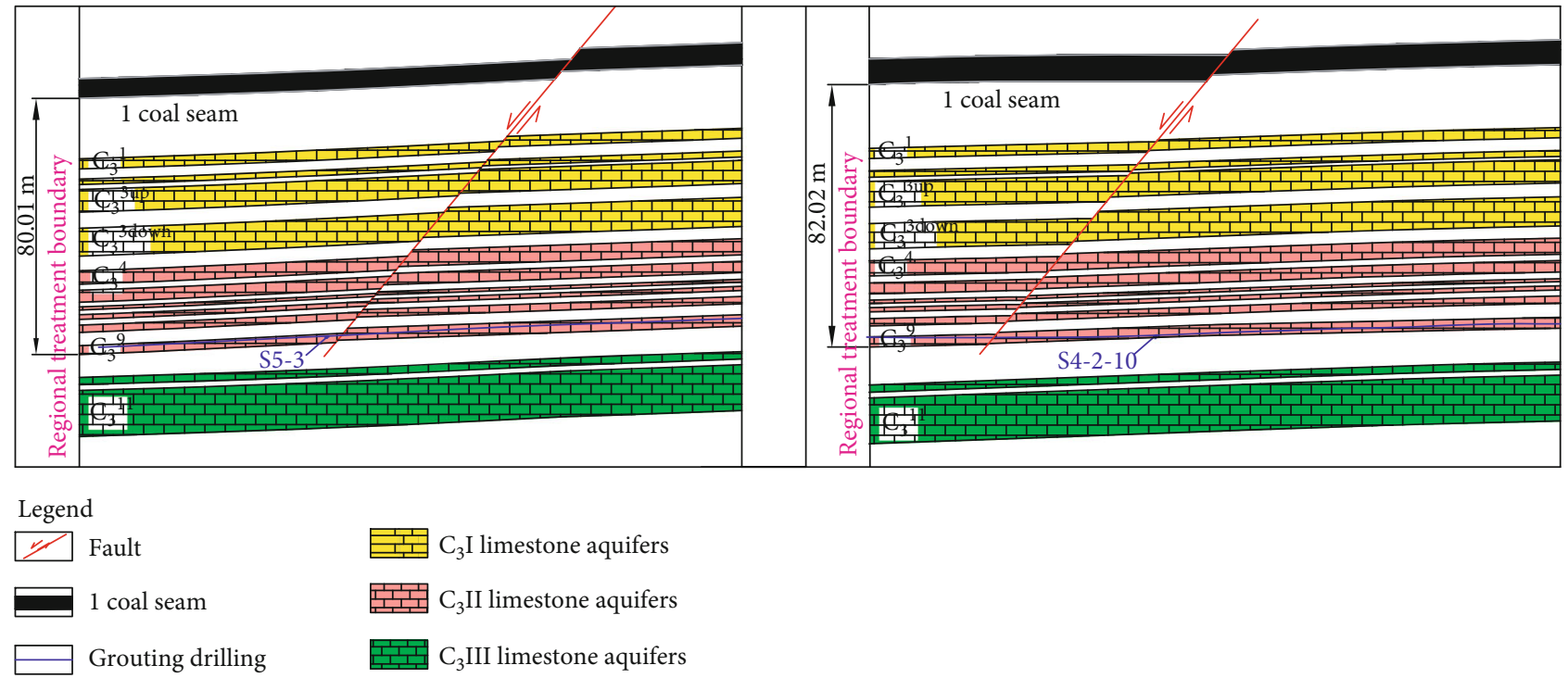

FIGURE 11: Cross-sectional drawing of S5-3 and S4-2-10, which are located in the $\mathrm{C}_{3}{ }^{9}$ limestone aquifer.

with the average thickness of $79.07 \mathrm{~m}$. Based on the data of ground area exploration and treatment, the data of S4-2-10 and $\mathrm{S} 5-3$ show that the lowest elevation of $\mathrm{C}_{3}{ }^{9}$ limestone floor is $-655.02 \mathrm{~m}$ and $-672.01 \mathrm{~m}$, respectively. Meanwhile, collecting the latest data of observation wells in Ordovician limestone aquifers, the water level ranges from $-6.18 \mathrm{~m}$ to $-13.57 \mathrm{~m}$. The water pressure in $\mathrm{C}_{3}{ }^{9}$ limestone floor can be reckoned as follow:

$$
P=\frac{H_{O} \max -H_{C_{3}{ }^{9}} \min }{100 \mathrm{~m} / \mathrm{MPa}}
$$

where $P$ is the Ordovician water pressure sustaining of $\mathrm{C}_{3}{ }^{9}$ limestone floor $(\mathrm{MPa}) ; H_{o} \max$ is the maximum elevation of Ordovician limestone water level $(\mathrm{m}) ; \mathrm{H}_{\mathrm{C}_{3}{ }^{9} \text { min }}$ is the minimum elevation of $\mathrm{C}_{3}{ }^{9}$ limestone floor $(\mathrm{m})$.

After calculation, the Ordovician water pressure sustaining of $\mathrm{C}_{3}{ }^{9}$ limestone floor in S4-2-10 and S5-3 is $6.59 \mathrm{MPa}$ and $6.66 \mathrm{MPa}$, respectively. As shown in Figure 11, the distance from 1 coal seam floor to $\mathrm{C}_{3}{ }^{9}$ limestone floor in S4-2-10 and S5-3 branch holes is $82.02 \mathrm{~m}$ and $80.01 \mathrm{~m}$, respectively. Taking the above parameters into Equation (3), then the water-inrush coefficient of Ordovician limestone is calculated to be $0.0803 \mathrm{MPa} / \mathrm{m}$ and $0.0832 \mathrm{MPa}$ in 13321 working face, respectively. Accepting the principle of caring about high not about low, the water-inrush coefficient of Ordovician limestone takes $0.0832 \mathrm{MPa}$ as the final assessment index.

\section{Conclusions}

To guarantee the safety mining of the 13321 working face, Gubei mine employs multimethods to detect the waterabundance zone distribution of the 1 coal seam roof and floor before and after regional treatment. On the basis of geophysical prospecting, underground drillings are launched to further confirm the results of the previous exploration; abnormal water-abundance zone threat to the working face is ascertained finally. The degree of water abundance in six low-resistance zones is weak, having no threat to excavate 1 coal seam, the detailed and reasonable conclusions are made in the study as follows:

(1) After the comprehensive exploration and analysis of the study area, the distance between the limestone aquifers in Carboniferous and 1 coal seam floor is only less than $20 \mathrm{~m}$. Exploiting 1 coal seam is likely to be affected by the deep limestone water if water hazard control and prevention projects are not carried out.

(2) Ground region treatment project is implemented to prevent limestone water damage, utilizing numerical analysis tool to guide and verify the ground grouting drilling layout. When the grouting pressure is $9 \mathrm{MPa}$, the dynamic viscosity is $0.008 \mathrm{~Pa} \cdot \mathrm{s}$, and the watercement ratio is 1.9 , the scale of slurry diffusion is up to about $30 \mathrm{~m}$. The value of project grouting parameters is not less than the standard value actually; the grouting parameters are verified to meet engineering requirements.

(3) While the regional treatment projects are thoroughly completed, the comprehensive geophysical prospecting and verification drillings implemented in roadways, combining with the data of ground observation wells, have confirmed the grouting effect to reach the control expectation. On the basis of analyzing exploration and drainage and geological drillings, the water-inrush coefficient of $\mathrm{C}_{3} \mathrm{I}$ limestone and Ordovician limestone in the working face floor is $0.0333 \mathrm{MPa}$ and $0.0832 \mathrm{MPa}$, which is less than the critical water-inrush coefficient. The effect of limestone water hazard control engineering meets the requirements of safety mining. 


\section{Data Availability}

The data used to support the findings of this study are included within the article.

\section{Conflicts of Interest}

The authors declare no conflict of interest.

\section{Authors' Contributions}

Jingzhong Zhu designed and wrote the paper, Seng Yang and Jiajun Fan collected the data for the paper, Ling Li and $\mathrm{Yu}$ Cui sorted and analyzed the material, and $\mathrm{Yu}$ Liu and Qimeng Liu reviewed and supervised the paper writing.

\section{Acknowledgments}

This research was supported by the Natural Science Foundation of Anhui Province (grant nos. 2008085QD191 and 1908085ME145), the Independent Research Fund of the State Key Laboratory of Mining Response and Disaster Prevention and Control in Deep Coal Mines (Anhui University of Science and Technology) (grant no. SKLMRDPC19ZZ06), and Anhui University of Science and Technology Graduate Innovation Fund Project (grant no. 2020CX2004). The authors gratefully appreciate the Gubei coal mine for providing the research data.

\section{References}

[1] J. Zhang, K. Xu, G. Reniers, and G. You, "Statistical analysis the characteristics of extraordinarily severe coal mine accidents (ESCMAs) in China from 1950 to 2018," Process Safety and Environment Protection, vol. 133, no. 2020, pp. 332-340, 2020.

[2] T. H. Yang, W. H. Shi, H. L. Liu, B. Yang, Y. Xin, and Z. B. Liu, "A non-linear flow model based on flow translation and its application in the mechanism analysis of water inrush through collapse pillar," Journal of China Coal Society, vol. 42, no. 2, pp. 315-321, 2017.

[3] F. Cui, Q. Wu, C. Xiong, X. Chen, F. Meng, and J. Peng, "Damage characteristics and mechanism of a 2010 disastrous groundwater inrush occurred at the Luotuoshan coalmine in Wuhai, Inner Mongolia, China," Water, vol. 12, no. 3, article 12030655, p. 655, 2020.

[4] H. S. Li and T. M. Liu, "Reflection of the Chinese disaster emergency preparedness system based on the analysis of the '3.28' Wang Jialing coal mine flooding accident rescue," Journal of Safety Science and Technology, vol. 6, no. 3, pp. 5-12, 2010.

[5] L. T. Gan, "Prevention of limestone water in coal floor of group A of Huainan mining area and causes analysis of water inrush accidents in Pan'er mine," Safety in Coal Mine, vol. 49, no. 7, pp. 171-175, 2018.

[6] L. Q. Shi, M. Qiu, Y. Wang, X. Qu, and T. Liu, "Evaluation of water inrush from underlying aquifers by using a modified water-inrush coefficient model and water-inrush index model: a case study in Feicheng coalfield, China," Hydrogeology Journal, vol. 27, no. 6, pp. 2105-2119, 2019.
[7] H. Niu, J. Wei, H. Yin, D. Xie, and W. Zhang, "An improved model to predict the water-inrush risk from an Ordovician limestone aquifer under coal seams: a case study of the Longgu coal mine in China," Carbonates and Evaporites, vol. 35, no. 3, p. 73, 2020.

[8] M. G. Qian, X. X. Miao, and J. L. Xu, Key strata theory of rock control, China University of Mining and Technology Press, $\mathrm{Xu}$ Zhou, 2003.

[9] "Mechanical behaviour and permeability evolution of gascontaining coal from unloading confining pressure tests," Journal of Natural Gas Science and Engineering, vol. 40, pp. 336-346, 2017.

[10] W. C. Zhu and C. H. Wei, "Numerical simulation on mininginduced water inrushes related to geologic structures using a damage-based hydromechanical model," Environmental Earth Sciences, vol. 62, no. 1, pp. 43-54, 2011.

[11] Y. Xue, T. Teng, L. Zhu et al., "Evaluation of the non-Darcy effect of water inrush from karst collapse columns by means of a nonlinear flow model," Water, vol. 10, no. 9, p. 1234, 2018.

[12] L. Xiao, Q. Wu, C. Niu et al., "Application of a new evaluation method for floor water inrush risk from the Ordovician fissure confined aquifer in Xiayukou coal mine, Shanxi, China," Carbonates and Evaporites, vol. 35, p. 97, 2020.

[13] X. Y. Wang, T. T. Wang, Q. Wang, X. Liu, R. Li, and B. J. Liu, "Evaluation of floor water inrush based on fractal theory and an improved analytic hierarchy process," International Journal of mine water, vol. 36, no. 1, pp. 87-95, 2017.

[14] X. Z. Shi, S. Y. Zhu, and W. Q. Zhang, "Study on the mechanisms and prevention of water inrush events in a deeply buried high-pressure coal seam-a case study of the Chensilou coal mine in China," Arabian Journal of Geosciences, vol. 12, no. 19, p. 614, 2019.

[15] J. T. Wang and X. L. Wang, "Discussion on water-inrush coefficient method applied to predict water-inrush danger of seam floor based on Gaojiata mine as example," Coal Science Technology, vol. 39, no. 7, pp. 106-111, 2011.

[16] Y. Wang, X. Yin, H. Jing, R. Liu, and H. Su, "A novel cloud model for risk analysis of water inrush in karst tunnels," Environmental Earth Sciences, vol. 75, no. 22, p. 1450, 2016.

[17] Y. Hu, W. Li, S. Liu, Q. Wang, and Z. Wang, "Risk assessment of water inrush from aquifers underlying the Qiuji coal mine in China," Arabian Journal of Geosciences, vol. 12, no. 3, p. 98, 2019.

[18] L. Q. Shi, Y. Wang, M. Qiu, W. Gao, and P. Zhai, "Application of three-dimensional high-density resistivity method in roof water advanced detection during working stope mining," Arabian Journal of Geosciences, vol. 12, no. 15, pp. 1-10, 2019.

[19] W. F. Gao, L. Q. Shi, and P. H. Zhai, "Water detection within the working face of an underground coal mine using 3D electric resistivity tomography (ERT)," Journal of Environmental and Engineering Geophysics, vol. 24, no. 3, pp. 497-505, 2019.

[20] Q. Yao, X. Li, J. Zhou, Q. Qu, and S. Cao, "Technology of coal seam floor grouting for disaster prevention and control while mining above a confined water body," Disaster Advanced, vol. 6, no. s5, pp. 216-227, 2013.

[21] Y. Qin and J. Lu, "Prediction of coal mine water hazards: a case study from the Huainan coalfield," Arabian Journal of Geosciences, vol. 12, no. 3, p. 83, 2019.

[22] J. Wang, J. Ma, K. Yang, S. Yao, and X. Shi, "Effects and laws analysis for the mining technique of grouting into the 
overburden bedding separation," Journal of Cleaner Production, vol. 288, article 125121, 2020.

[23] L. Q. Shi, C. S. Bo, and J. C. Wei, "Control theory and technology of Ordovician limestone karst water-inrush in north China coalfield," China Coal Industry Publishing House, Beijing, 2015.

[24] W. Qiao, W. P. Li, H. C. Chai, X. Zhang, Y. K. Chen, and B. H. Bai, Prevention and control theory and technology of karst water mining in deep mines, Geol. Publishing, Beijing, 2018.

[25] W. F. Gao, L. Q. Shi, J. Han, and P. Zhai, "Study on control water of Ordovician aquifer: a coal mine of Feicheng mining area, China," Carbonates and Evaporites, vol. 35, no. 2, p. 48, 2020.

[26] D. Qian, N. Zhang, M. Zhang et al., "Application and evaluation of ground surface pre-grouting reinforcement for $800 \mathrm{~m}$ deep underground opening through large fault zones," Arabian Journal of Geosciences, vol. 12, no. 13, p. 285, 2017.

[27] H. Wang, "Application and development of directional drilling technology in strata grouting transformation for coal mines in China," Coal Engineering, vol. 49, no. 9, pp. 1-5, 2017.

[28] X. L. Wang, Q. R. Qin, and C. H. Fan, "Research on comprehensive evaluation for grouting effect of broken and soft floor," Arabian Journal of Geosciences, vol. 10, no. 19, p. 420, 2017.

[29] J. Wei, G. Yu, D. Xie et al., "Drainage feasibility of a Carboniferous thin-layer limestone aquifer based on a dewatering test: Luxi coal mine, China," Carbonates and Evaporites, vol. 35, no. 3 , p. $80,2020$.

[30] H. B. Shang, D. W. Jin, C. H. Zhao et al., "Transport law of curtain grouting fluid in conglomerate aquifer and evaluation of rock mass modification effect," Journal of China Coal Society, vol. 44, no. 8, pp. 2460-2469, 2019.

[31] C. H. Han, W. J. Zhang, W. W. Zhou et al., "Experimental investigation of the fracture grouting efficiency with consideration of the viscosity variation under dynamic pressure conditions," Carbonates and Evaporites, vol. 35, no. 2, p. 30, 2020.

[32] Q. C. Zhang, J. H. Li, B. S. Liu, and X. Chen, "Directional drainage grouting technology of coal mine water damage treatment,” Procedia Engineering, vol. 26, pp. 264-270, 2011.

[33] W. Qiao, W. P. Li, and X. Zhang, "Characteristic of water chemistry and hydrodynamics of deep karst and its influence on deep coal mining," Arabian Journal of Geosciences, vol. 7, no. 4, pp. 1261-1275, 2014.

[34] K. Chudy, M. Worsa-Kozak, and A. Wójcik, "Groundwater chemistry and stratification in the flooded hard-coal mine shaft "Nowy I" (Nowa Ruda Region, SW Poland)," Water, vol. 12, no. 11, p. 3257, 2020.

[35] Y. Guo, H. Gui, J. Wei et al., "Hydro-geochemistry of water in coal measures during grouting treatment of Taoyuan mine, China," Groundwater, vol. 59, no. 2, pp. 256-265, 2020.

[36] H. Li, H. Bai, J. Wu et al., "Mechanism of water inrush driven by grouting and control measures-a case study of Chensilou mine China," Arabian Journal of Geosciences, vol. 10, p. 468, 2017.

[37] S. C. M. S. S. Bureau, "Coal mine water prevention and control regulation coal industry press," State Coal Mine Safety Supervision Bureau, Beijing, 2018. 